\title{
PENGARUH PEER ASSESMENT MENGGUNAKAN PROBLEM POSING TERHADAP HASIL BELAJAR SISWA PADA MATERI LAJU REAKSI DI SMAN 1 ALALAK
}

\section{The Effect Of Peer Assesment Using Problem Posing On Student Learning Outcomes In The Material Reaction Rate In SMAN 1 Alalak}

\author{
Erika Nada Depani, Herlina Apriani, Raden Roro Ariessanty Alicia Kusuma \\ Wardhani \\ Program Studi Pendidikan Kimia Fakultas Keguruan dan Ilmu Pendidikan \\ Universitas Islam Kalimantan (Uniska) Muhammad Arsyad Al Banjari, Banjarmasin \\ email:nadaendefa@gmail.com
}

\begin{abstract}
Abstrak. Penelitian ini bertujuan untuk mengetahui pengaruh peer assesment menggunakan problem posing terhadap hasil belajar siswa pada materi laju reaksi di SMAN 1 Alalak. Penelitian ini dilaksanakan di SMA Negeri 1 Alalak Handil Bakti, Barito Kuala, Kalimantan Selatan, menggunakan metode eksperimen yang melibatkan dua kelompok belajar yakni kelas eksperimen dan kelas kontrol dengan desain penelitian posstest-only control group design. Sampel dalam penelitian ini sebanyak 58 sampel yang terdiri dari kelas eksperimen berjumlah 29 siswa dan kelas kontrol berjumlah 29 siswa. Instrumen untuk mengumpulkan data pada penelitian ini adalah soal tes pilihan ganda. Hasil penelitian menunjukkan bahwa pembelajaran peer assessment menggunakan model problem posing mampu meningkatkan hasil belajar siswa pada materi laju reaksi di SMAN 1 Alalak. Hal ini dapat dilihat pada hasil uji hipotesis yang menggunakan uji mann-whitney, dengan hasil sig yang didapatkan adalah 0,00 yang mana signya $<0,05$, sehingga $\mathrm{H}_{0}$ ditolak dan $\mathrm{H}_{1}$ diterima.
\end{abstract}

Kata Kunci: Peer Assesment, Hasil belajar, Problem Posing, Laju Reaksi.

\begin{abstract}
This study aims to determine the effect of peer assessment using problem posing on student learning outcomes in the reaction rate material at SMAN 1 Alalak. This research was conducted at Alalak Handil Bakti 1 Public High School, Barito Kuala, South Kalimantan, using an experimental method that involved two study groups namely the experimental class and the control class with the research design posstest-only control group design. The sample in this study were 58 samples consisting of 29 students in the experimental class and 29 students in the control class. The instrument to collect data in this study was a multiple choice test. The results showed that peer assessment learning using the problem posing model was able to improve student learning outcomes in the reaction rate material at SMAN 1 Alalak. This can be seen in the results of hypothesis testing using the mann-whitney test, with the result of the sig obtained is 0.00 which sig is $<0.05$, so $H_{0}$ is rejected and $H_{1}$ is accepted.
\end{abstract}

Keywords: Peer Assessment, Learning Outcomes, Problem Posing, The Reaction Rate. 


\section{PENDAHULUAN}

Pendidikan merupakan hal yang sangat penting dalam upaya meningkatkan mutu sumber daya manusia untuk membangun negeri yang lebih baik. Dasar suatu pendidikan tersebut salah satunya kita dapati dibangku sekolah. Sekolah adalah lembaga pendidikan yang melaksanakan kegiatan yang disebut dengan pembelajaran. Karena pendidikan adibangku sekolah merupakan hal yang sangat penting, pemerintah menerapkan wajib belajar 12 tahun. Pembelajaran yang dilaksanakan disekolah dibagi menjadi beberapa mata pelajaran. Salah satu mata pelajaran wajib tingkat SMA/MA adalah kimia. Kimia merupakan salah satu cabang sains atau dikenal dengan Ilmu Pengetahuan Alam (IPA). Penelitian di beberapa Negara menunjukkan bahwa sains, terutama kimia serta fisika menjadi salah satu mata pelajaran yang kurang disukai di kalangan siswa. Salah satu materi kimia yang kurang dipahami siswa adalah materi laju reaksi. Laju reaksi merupakan salah satu pokok bahasan yang memaparkan tentang seberapa cepat atau lambat suatu reaktan habis atau suatu produk terbentuk (Manitoba, 2013). Selain itu beberapa penelitian menunjukkan bahwa terjadi kesulitan memahami konsep-konsep kimia karena ketidakmampuan menghubungkan dunia makroskopis dan mikroskopis seperti konsep mol, struktur atom, teori kinetik, perubahan kimia, penyetaraan persamaan reaksi dan stereo kimia (Purtadi, 2006).

Kesulitan siswa dalam memahami materi laju reaksi, dialami oleh siswa kelas XI MIA di SMA Negeri 1 Alalak. Ketuntasan hasil belajar siswa di SMA Negeri 1 Alalak pada materi laju reaksi tahun pelajaran 2016/2017 hanya sebesar 35\%. Selain karena tingkat kesulitan dalam hal memahami materi, penyebab lain yang menyebabkan hasil belajar siswa rendah adalah kondisi pembelajaran di SMAN 1 Alalak masih bersifat konvensional tanpa melibatkan siswa untuk berperan aktif didalam proses pembelajaran. Hal tersebut disampaikan oleh guru kimia di SMAN 1 Alalak dalam sesi wawancara yang telah dilakukan sebelum pelaksanaan penelitian.

Salah satu upaya yang dapat digunakan untuk membuat pembelajaran lebih efektif dan melibatkan siswa dalam proses pembelajaran adalah problem posing. Problem posing berasal dari dua kata bahasa inggris yaitu problem dan posing. "Problem" berarti masalah atau soal dan "posing" berasal dari kata "to pose" yang artinya mengajukan atau membentuk, sehingga Problem posing diartikan sebagai pengajuan atau pembentukan soal atau masalah (Iskandar, 2011).

Pada model Problem posing, ditinjau dari struktur pembelajarannya, terdapat bagian yang berpusat pada guru dan berpusat pada siswa (Iskandar, 2011). Bagian yang berpusat pada guru berupa penyampaian materi diawal pembelajaran dan bagian yang berpusat pada siswa berupa kegiatan membuat atau menyelesaikan soal. Namun pada model Problem posing, kegiatan membuat soal menjadi fokus utama pembelajaran, artinya model pembelajaran ini lebih berorientasi ke teori konstruktivisme. Untuk memaksimalkan bagian yang berpusat pada siswa, perlu pula adanya umpan balik. Umpan balik tersebut diperoleh dari guru atau sesama siswa. Pada penelitan ini umpan balik didapatkan dari sesama siswa melalui peer assessment. Melalui peer assessment siswa dapat saling membantu untuk mendapatkan kinerja yang lebih baik dari proses pembelajaran. Beberapa keuntungan potensial dari penilaian teman bagi siswa diantaranya adalah memberikan rasa kepemilikan dari proses penilaian, peningkatan motivasi, mendorong siswa untuk bertanggung jawab atas pembelajaran bagi mereka sendiri, mengembangkan siswa sebagai pembelajar mandiri, memperlakukan penilaian 
sebagai bagian dari pembelajaran, sehingga kesalahan tersebut adalah kesempatan untuk memperbaiki kegagalan, mempraktekkan keterampilan yang dibutuhkan untuk belajar, terutama keterampilan evaluasi (Brown, Gibbs 1994).

\section{METODE PENELITIAN}

Penelitian ini merupakan jenis eksperimen semu, dengan desain penelitian posstest-only control group design. Penelitian ini dilaksanakan di SMA Negeri 1 Alalak, Jl. Brigjend H. Hasan Basri Km.11 Handil Bakti, Barito Kuala, Kalimantan Selatan, Indonesia. Populasi dalam penelitian ini adalah siswa kelas XI MIA SMA Negeri 1 Alalak tahun ajaran 2018/2019. Teknik pengambilan sampel pada penelitian ini adalah teknik Cluster Sampling. Sampel penelitian ini terdiri dari dua kelas, yakni kelas XI MIA sebagai kelas eksperimen dan kelas XI MIA 2 sebagai kelas kontrol. Jumlah sampel keseluruhan adalah 58 siswa yang mana tiap kelas berisi 29 siswa. Teknik pengumpulan data menggunakan soal tes kognitif berbentuk pilihan ganda berjumlah 15 soal dengan lima pilihan jawaban. Hasil data yang telah diperoleh di analisis menggunakan uji Mann Whitney- $U$ untuk mengetahui ada atau tidaknya pengaruh menggunakan peer assessment dengan problem posing dikelas eksperimen dan kelas kontrol yang hanya menggunakan problem posing saja. Rancangan penelitian tersebut dapat dilihat pada Tabel 1.

Tabel 1: Rancangan penelitian

\begin{tabular}{ccc}
\hline Kelompok & Perlakuan & Posttest \\
\hline Kontrol & $\mathrm{X}_{1}$ & $\mathrm{O}_{1}$ \\
Eksperimen & $\mathrm{X}_{2}$ & $\mathrm{O}_{2}$ \\
\hline
\end{tabular}

Keterangan:

$\mathrm{X}_{1}$ : Penerapan Peer Assesment

$\mathrm{X}_{2}$ : Penerapan Peer Assesment menggunakan problem posing

$\mathrm{O}_{1}$ : Postest kelas kontrol

$\mathrm{X}_{2}$ : Postest kelas eksperimen

Instrumen penelitian pada penelitian ini telah divalidasi oleh 5 ahli, yakni 2 orang dosen Pendidikan Kimia UNISKA dan 3 orang guru mata pelajaran kimia. Instrumen untuk mengukur hasil belajar siswa berupa tes kognitif berbentuk pilihan ganda berjumlah 15 soal dengan 5 pilihan jawaban. Kemudian data hasil belajar yang sudah diperoleh akan dianalisis dengan bantuan aplikasi SPSS.

\section{HASIL DAN PEMBAHASAN}

Penelitian ini di uji cobakan pada 2 kelas sebagai sampelnya, yakni kelas XI MIA 1 sebagai kelas eksperiment dan kelas XI MIA 2 sebagai kelas kontrol. Pada masingmasing kelas dilakukan 5 kali pertemuan untuk satu materi pokok. Kedua kelas diberikan alokasi waktu yang sama untuk setiap kali pertemuan yaitu 2 x 45 menit. Penerapan peer assessment melalui problem posing diaplikasikan pada kelas eskperimen sedangkan kelas kontrol hanya diterapkan model pembelajaran problem posing tanpa peer assessment.

Pada pertemuan pertama, masing-masing kelas diberikan pengetahuan awal sebagai tahap awal pembelajaran. Kemudian pada pertemuan kedua, ketiga dan keempat 
baik kelas eksperimen maupun kelas kontrol diberikan pembelajaran tentang materi pokok laju reaksi dengan pembagian submateri yang sama. Ditengah-tengah proses pembelajaran, setelah guru selesai menerangkan penjelasannya, siswa diminta untuk membuat soal sesuai dengan arahan dari guru. Karena pada penelitian ini menggunakan problem posing tipe semi bebas, siswa diarahkan untuk membuat soal dengan materi yang telah ditentukan. Sembari membuat soal siswa yang bersangkutan juga harus pula menyiapkan jawaban dari soal yang telah dibuatnya. Siswa diberi kebebasan dalam membuat soal sesuai dengan materi yang telah diajarkan. Pada kelas eksperimen setelah selesai membuat soal siswa diminta untuk menukarnya pada teman sebangkunya, pada tahap ini proses peer assessment sedang berlangsung. Siswa diberi waktu untuk menilai hasil kinerja temannya dengan menggunakan angket yang telah disiapkan. Disinilah letak perbedaan perlakuan yang diberikan pada kelas eksperimen dan kelas kontrol. Kemudian pada pertemuan ke lima kedua kelas diberikan soal posttest untuk mengetahui perbedaan hasil belajar kedua kelas.

Data hasil belajar siswa yang telah diperoleh selanjutanya dianalisis dengan menggunakan bantuan aplikasi SPSS. Sebelum melakukan anaalisis uji hipotesis, terlebih dahulu harus dilakukan uji analisis prasyarat. Uji prasyarat terdiri dari uji normalitas dan uji homogenitas yang tertera pada tabel 2 dan tabel 3 dibawah ini.

Tabel 2. Tabel Uji Normalitas

\begin{tabular}{cccccccc}
\hline & & \multicolumn{2}{c}{ Kolmogorov-Smirnov $^{\text {a }}$} & \multicolumn{3}{c}{ Shapiro-Wilk } \\
\hline & Kelas & Statistic & df & Sig. & Statistic & df & Sig. \\
\hline Nilai & Kelas Eksperimen & .210 & 29 & .002 & .889 & 29 & .0 .09 \\
\hline Kelas Kontrol & .196 & 29 & .006 & .913 & 29 & .0 .21 \\
\hline
\end{tabular}

a. Lilliefors Significance Correction

Tabel 3. Uji Homogenitas

\begin{tabular}{|c|c|c|c|c|c|}
\hline Nilai & & & & & \\
\hline & Sum of Squares & & Mean & & \\
\hline & & df & Square & $\mathrm{F}$ & Sig. \\
\hline Between Groups & 224.069 & 1 & 224.069 & 6.842 & 0,11 \\
\hline Within Groups & 1834.000 & 56 & 32.750 & & \\
\hline Total & 2058.069 & 57 & & & \\
\hline
\end{tabular}

Berdasarkan tabel uji normalitas, dapat kita lihat bahwa sig kelas eksperimen $<0,05$. Hal tersebut menandakan data untuk kedua kelas tidak terdistribusi dengan normal. Suatu data dapat dikatakan terdistribusi dengan normal apabila sig > 0,05 (Sugiyono, 2010). Sedangkan pada tabel uji homogenitas didapatkan nilai sig 0,11. Varians kedua sampel ini dapat dikatakan homogen karena signya > 0,05 (Sarwono, 2012).

Dari hasil uji homogenitas dan uji normalitas, diketahui bahwa pada penelitian ini data tidak terdistribusi normal dan homogen. Oleh sebab itu, maka untuk uji hipotesisnya menggunakan uji Mann Whitney-U. Uji Mann Whitney-U adalah uji nonparametrik yang digunakan untuk mengetahui perbedaan median dua kelompok bebas. Data hasil uji Mann Whitney-U dapat dilihat pada tabel 4 berikut. 
Tabel 4: Uji Hipotesis Mann Whitney U

\begin{tabular}{|c|c|}
\hline Mann-Whitney U & 37.000 \\
\hline Wilcoxon Q & 472.000 \\
\hline $\mathrm{Z}$ & -6.049 \\
\hline $\begin{array}{c}\text { Asymp. Sig. (2- } \\
\text { tailed) }\end{array}$ & .000 \\
\hline
\end{tabular}

Berdasarkan tabel 4 di atas didapatkan signya adalah 0,00. Dan berdasarkan dasar pengambilan keputusan pada uji mann whitney-U, diketahui sig $<0,05$ yang berarti $\mathrm{H}_{0}$ ditolak, $\mathrm{H}_{1}$ diterima (Arikunto, 2009). Data hipotesis ini menunjukkan bahwa terdapat pengaruh penerapan peer assessment menggunakan problem posing terhadap hasil belajar siswa pada materi laju reaksi di SMAN 1 Alalak.

Penerapan peer assessment menggunakan model problem posing terbukti berpengaruh positif terhadap hasil belajar dan siswa di SMAN 1 Alalak. Hasil penelitian ini sesuai dengan penelitian (Ariyani, 2018) yang menjelaskan bahwa penerapan peer assessment dapat meningkatkan hasil belajar siswa. Melalui kegiatan yang melibatkan peserta didik dalam proses penilaian, peserta didik mampu mengembangkan kerjasama, mengkritisi proses dari hasil belajar orang lain, menerima feedback atau kritik dari orang lain (Zulharman, 2007). Proses mengkritisi inilah siswa dituntut untuk kreatif dalam menguasai materi. Hal ini membuktikan bahwa penerapan peer assessment menggunakan model problem posing baik digunakan dalam proses pembelajaran terutama untuk meningkatkan hasil belajar. Dari beberapa ulasan diatas, penerapan peer assessment dapat meningkatkan hasil belajar karena siswa didorong untuk mengkaji ulang materi yang telah diterimanya melalui pembuatan soal serta dituntut untuk menilai secara kritis hasil kerja yang dilakukan oleh teman sejawatnya. Tidak hanya itu, siswa juga diminta untuk mengkritik atau mengomentari hasil kinerja teman sejawatnya, sehingga feedback yang didapatkan tiap siswa menjadi maksimal. Pada penelitian ini keefektifan penerapaan peer assessment terhadap hasil belajar siswa sangat didukung oleh problem posing, karena problem posing melatih otak peserta didik untuk mengembangkan topik permasalahan secara kreatif yang dituangkan dalam pembuatan soal, sehingga hal tersebut menyebabkan peserta didik mudah mengingat apa yang sudah dilakukan dalam otaknya dan mampu menjadi memori jangka panjang bagi peserta didik yang nantinya akan berpengaruh pada hasil belajar kognitif yang lebih baik (Nugroho, 2013). Keefektifan peer assessment dan model problem posing akan membantu siswa dan guru mendapatkan kinerja yang maksimal dalam proses pembelajaran (Brown, Gibbs 1994) dan membentuk kemampuan serta pengetahuan siswa terkadap konsep laju reaksi dengan lebih baik lagi.

\section{SIMPULAN}

Berdasarkan pembahasan dari data hasil penelitian yang telah dipaparkan, dapat disimpulkan bahwa penerapan peer assessment menggunakan model problem posing mampu meningkatkan hasil belajar siswa. 


\section{DAFTAR RUJUKAN}

Ariyani, S., Apriani, H., Akhyar, O. (2018). Pengaruh Penerapan Peer Assessment Melalui Model Team Assisted Individualzation (TAI) pada Materi Kelarutan dan Hasil Kali Kelarutan Terhadap Hasil Belajar Siswa di SMAN 9 Banjarmasin. Dalton: Jurnal Pendidikan Kimia dan Ilmu Kimia. 1 (2) 34-39.

Arikunto, S. (2007). Dasar-Dasar Evaluasi Pendidikan (Edisi Revisi). Jakarta: Bumi Aksara.

Arikunto, S., (2009). Prosedur Penelitian Suatu Pendekatan Praktik. Edisi Revisi 6. Jakarta : Rineka Cipta.

Brown, S., Rust, C. dan Gibbs, G. (1994). Involving Students in the Assessment Process, in Strategies for Diversifying Assessments in Higher Education, Oxford: Oxford Centre for Staff Development, and at Deliberations.

Iskandar, S. M. (2011). Pendekatan Pembelajaran Sains Berbasis Konstruktivis. Malang: Bayumedia.

Rudi, Apriani, H., Wardhani, R.R.A.A.K. (2018). Pengaruh Penerapan Peer Assessment Melalui Mind Mapping Terhadap Hasil Belajar Siswa Pada Materi Sistem Koloid. Vidya Karya. 33 (2) 163-167.

Sarwono, J. (2012). IBM SPSS “Advances Statistic”: Prosedur-Prosedur Generalisasi dan Perluasan General Linear Model (GLM). Yogyakarta: ANDI

Sugiyono. (2010). Metode Penelitian Kuantitatif Kualitatif \& RND. Bandung: Alfabeta

Manitoba. (2013). Grade 12 Chemistry: A Foundation for Implementation. Winnipeg: Manitoba Education School Program Division.

Zulharman. (2007). Self dan Peer Assessment Sebagai Penilaian Formatif dan Sumatif. Skripsi. Yogyakarta: Fakultas Kedokteran Universitas Gadjah Mada. 